\title{
O IMPACTO DAS REFORMAS POLÍTICO-EDUCACIONAIS DO BRASIL - 1925- 1940 - NO ENSINO DE LÍNGUA PORTUGUESA
}

\author{
THE IMPACT OF POLITICAL AND EDUCATIONAL REFORMS OF BRAZIL - 1925- \\ 1940 - TEACHING OF PORTUGUESE LANGUAGE
}

Submetido em: 13-12-2012

Publicado em: 23-02- 2013

Josa Coelho Irigoite ${ }^{1}$ josa_coelho@hotmail.com. Rosângela Pedralli

\begin{abstract}
Resumo: É objeto da presente pesquisa a compreensão do possível impacto que as reformas político-educacionais ocorridas entre os anos de 1925 e 1940 tiveram sobre o ensino de Língua Portuguesa. Obviamente, como se trata de um estudo que tem por base histórias orais, acabam sendo contempladas, quando da análise de dados, remissões a outras disciplinas escolares. O trabalho tem como eixo as memórias dos períodos discente e docente de uma professora aposentada de 93 anos de idade. A metodologia empregada foi, assim, história oral (HO) gerada a partir de entrevista semiestruturada. O percurso analítico foi norteado pelo interesse em responder à seguinte questão de pesquisa: como as reformas políticas na educação do Brasil, no período entre 1925 e 1940, incidiram nas ações educativas da época, principalmente no que compete à disciplina de Língua Portuguesa?
\end{abstract}

Palavras-chave: Reformas político-educacionais. Ensino de Língua Portuguesa. História oral.

\begin{abstract}
The purpose of the present study is to understand the possible impact that political and educational reforms that occurred between the years 1925 and 1940 had on the teaching of the Portuguese Language. Obviously, as this is a study that is based on oral histories, end up being included when analyzing data, references to other school subjects. The work has the axis memories of times students and professors of a retired teacher of 93 years old. The methodology employed was thus oral history (HO) generated from semistructured interview. The analytical path was guided by an interest in answering the following research question: How political reforms in education in Brazil, in the period

\footnotetext{
${ }^{1}$ Doutoranda pelo Programa de Pós-graduação em Linguística da Universidade Federal de Santa Catarina. Email: josa_coelho@hotmail.com.

${ }^{2}$ Doutoranda pelo Programa de Pós-graduação em Linguística da Universidade Federal de Santa Catarina. Email: rosangelapedralli@hotmail.com.
}

Work. pap. linguíst., 13(2): 123- 138, Florianópolis, jul.set,2012 
between 1925 and 1940, focused on educational activities of the time, especially in the racing discipline Portuguese Language?

Keywords: Political and educational reforms. Teaching of Portuguese Language. Oral history.

\section{Introdução}

O interesse, das áreas da Educação e da Linguística, em reconstruir a história da Língua Portuguesa como disciplina escolar é relativamente recente. As dificuldades de acesso a registros escritos de determinados períodos históricos são significativas. Desse modo, entendemos que a reconstrução de determinados períodos históricos pode ser enriquecida a partir de outras estratégias de pesquisa como relato de memórias relativas tanto ao processo de escolarização quanto ao percurso docente.

É objeto deste artigo, assim, a compreensão das mudanças educacionais no período histórico de 1925 a 1940. Tal proposta se dá a partir de memórias dos períodos discente e docente de uma professora aposentada de 93 anos de idade. A metodologia empregada será a história oral (HO) gerada a partir de entrevista semiestruturada. O percurso analítico foi norteado pelo interesse em responder à seguinte questão de pesquisa: como as reformas políticas na educação do Brasil, no período entre 1925 e 1940, incidiram nas ações educacionais da época, principalmente no que compete à disciplina de Língua Portuguesa?

Tal questão materializa nosso objetivo com este estudo: compreender em que medida e de que forma as reformas de caráter político governamental da educação do Brasil, no período entre 1925 e 1940, incidiram, efetivamente, nas ações educativas do período, especialmente em se tratando da disciplina de Língua Portuguesa.

Essa pesquisa se justifica pelo fato de existir ainda uma carência de estudos acerca da história da disciplina de Língua Portuguesa, bem como da educação institucionalizada no Brasil de forma geral, embora o número de estudos dessa natureza tenha crescido nos últimos anos, a exemplo de Razzini (2000) e Friedemann (2010), citadas neste trabalho. Isso se deve, em grande medida, à escassez de registros documentais e materiais escritos dos diferentes períodos históricos, o que acaba por originar estudos que se limitam ao traçado cronológico das reformas políticas em nível nacional e não tratam objetivamente do impacto efetivo dessas reformas nas ações educativas.

Assim, acreditamos que interessa à área de Linguística Aplicada, especialmente, reconstruir a história da disciplina Língua Portuguesa para, a partir dela, compreender melhor o cenário atual da esfera escolar a fim de ressignificá-lo, o que poderia facultar ações educativas com vista à implementação dos usos da língua mais consequentes. À luz desse interesse, no qual se ancora nossa pesquisa, contamos com Razzini (2000), Soares (2002) e Daniel (2001), textos que historiam a educação no Brasil, para situar historicamente os relatos da participante; e com Friedemann (2010), Janotti (2010) e Smith (2010), que embasam teoricamente nossa pesquisa no que compete às narrativas orais.

Para dar conta da discussão proposta, este trabalho conta com duas seções, a saber: (1) A geração de dados a partir de relatos orais - seção na qual são discutidos os aspectos

Work. pap. linguíst., 13(2): 123- 138, Florianópolis, jul.set,2012 
metodológicos do estudo; e (2) $O$ relato da participante e o contexto histórico: reconstruindo a história da educação no Brasil entre os anos de 1925 e 1940 - seção na qual os dados, fruto dessa abordagem metodológica, são descritos e analisados, obedecendo ao critério cronológico; além das considerações finais. Eis, então, o que segue.

\section{A geração de dados a partir de relatos orais}

O trabalho com relatos orais com vistas a reconstituir um determinado período histórico é algo relativamente novo quando tomado à luz das metodologias de pesquisa. Segundo Janotti (2010, p. 11), foi na década de 1970 que a história oral "[...] quebrou uma série de paradigmas anteriores e continua em fase de construir seus próprios". Essa metodologia, de acordo com a autora, passa por um processo de aprimoramento de suas técnicas e de defesa de sua constituição como um campo próprio e interdisciplinar.

A história oral como metodologia prospera, no entendimento de Smith (2010, p.

27), “[...] quando ultrapassa o modelo de simples coleção de histórias pessoais e se transforma em diálogo sobre o passado, estimulando novas interpretações históricas". Para o autor (2010, p. 27), ainda, "[...] o relato que eu conto só tem sentido quando estimula novas interpretações. Uma vez compartilhada, já deixa de ser a minha própria história". Cada nova entrevista, dessa forma, pode ser compreendida como um convite a uma cadeia de diálogos. A história oral, ainda, pode democratizar o entendimento do passado ao permitir que imaginemos "[...] a nossa experiência pessoal como algo que existe para ser compartilhado, como algo que poderia ser útil para uma comunidade de investigação mais ampla do que podemos imaginar" (SMITH, 2010, p. 27).

Ao contrário do que normalmente ocorre com as outras metodologias utilizadas na reconstrução de períodos históricos determinados, nas histórias orais não são recolhidos papéis (cartas, documentos etc.). As percepções, as histórias, as observações, enfim, não ficam armazenadas em algum lugar à espera de recuperação (SMITH, 2010). Elas não têm existência física antes que o contato entre entrevistador e entrevistado se dê, ou, nas palavras de Smith (2010, p. 28), "[...] elas não têm existência física antes do entrevistador e do entrevistado se sentarem juntos em frente a um gravador; elas não têm existência, nem mesmo imaterial". Os relatos dessa natureza são importantes na medida em que evidenciam "[...] formas de vida coletiva que são difíceis (embora não sejam impossíveis) de documentar de outras maneiras" (SMITH, 2010, p. 29).

Não obstante, pesquisas via fontes orais não podem objetivar relatos diretos de fatos ocorridos no passado. Isso porque "A linguagem comunica porque cria a 'experiência' em formas convencionais" (SMITH, 2010, p. 30); logo, relatos orais são sempre uma criação a partir das vivências do sujeito e não relato literal. Para Smith (2010), a recorrência de narrativas de aspectos do passado facilita a repetição das palavras aprendidas. Os relatos orais são, por natureza, simbólicos, ou seja, “[...] o objetivo é comunicar um julgamento sobre o que aconteceu; convidar outra pessoa para compartilhar a perspectiva emocional do narrador" (SMITH, 2010, p. 30).

Outro ponto importante a destacar da história oral é o trabalho com a memória. Friedemann (2010) assevera, ancorada nas afirmações de Bosi (1995), que, ao recuperar o passado, ao reconstruir as memórias, está também se projetando o futuro e alterando o

Work. pap. linguíst., 13(2): 123- 138, Florianópolis, jul.set,2012 
presente. Como diz a autora (2010, p. 44), a memória é trabalho, visto que, em grande parte das vezes, "[...] lembrar não é reviver, mas refazer, construir, repensar, com imagens e ideias de hoje, as experiências do passado. A memória não é sonho, é trabalho".

Nesse ponto, Friedemann (2010, p. 62), em convergência com a compreensão de Smith (2010), afirma que conceber a memória como trabalho evidencia “[...] a importância do tempo presente no processo de rememoração, já que as memórias são ativadas pelas situações atuais, pelos objetos e lembranças que temos a nossa disposição, que, por sua vez, são ativados através das relações com o outro". Assim, "[recuperar a história] significa buscar a compreensão de seu processo de formação tendo em vista o contexto em que essa história se desenvolveu" (FRIEDEMANN, 2010, p. 47).

Delineada a metodologia da pesquisa, partimos para a entrevista com a participante: uma professora aposentada de 93 anos que cursou todo o ensino primário no município de Florianópolis/SC, entre os anos de 1925 a 1937 (veremos a cronologia dessa formação na próxima seção), e ministrou aulas no município de Araranguá/SC por mais de 30 anos, no ensino primário em classes multisseriadas, conforme parece indicar o relato. Marconi e Lakatos (2007, p. 197) definem a entrevista como: "[...] um encontro entre duas pessoas, a fim de que uma delas obtenha informações a respeito de determinado assunto, mediante uma conversação de natureza profissional".

Para alguns autores, assim, ela é considerada o instrumento por excelência da investigação social, pois normalmente gera muito mais dados importantes do que aqueles obtidos na observação da realidade objeto de pesquisa. Marconi e Lakatos (2007) ainda levantam como vantagens da entrevista: pode ser utilizada com todos os segmentos da população; fornece uma amostragem muito melhor da população geral, pois o entrevistado não precisa saber ler ou escrever; é flexível, pois o entrevistador pode repetir ou esclarecer perguntas na hora, para melhor ser compreendido; oferece oportunidade para avaliar atitudes, condutas, pois o entrevistado pode ser observado nas reações e gestos; pode gerar dados que não se encontrem em fontes documentais e que sejam relevantes e significativos; possibilita conseguir informações mais precisas; permite que os dados sejam quantificados e submetidos a tratamento estatístico. No caso de nosso estudo, a entrevista foi a ferramenta utilizada para geração de dados, as memórias de uma pessoa que viveu nesse período como estudante e que hoje relata tal período na perspectiva de docente aposentada que é, por parecer-nos a melhor fonte para delinearmos tal época histórica.

Realizamos por ocasião do estudo dois momentos pontuais de interação com a participante da pesquisa durante o mês de outubro de 2011. No primeiro momento, esperávamos uma interação do tipo relato oral livre, ou seja, não previmos nenhum roteiro, era nosso objetivo ouvir as memórias da participante acerca do período de discência e docência; entretanto, tivemos dificuldade em obter informações relativamente precisas da participante. No segundo momento, nossa interação com a participante foi pautada em uma entrevista semiestruturada (MARCONI; LAKATOS, 2007). Durante tal interação, assim, não mantivemos o roteiro de maneira rígida, ou por outra, mencionávamos determinadas reformas ou períodos político-educacionais, acerca dos quais a participante discorria e a partir do que fazíamos novas perguntas ou passávamos para outro tópico. Os dois momentos de interação foram gravados e, posteriormente, transcritos. Os relatos da participante, relacionados com o contexto histórico da época em questão, serão descritos e analisados na seção que segue.

Work. pap. linguíst., 13(2): 123- 138, Florianópolis, jul.set,2012 


\section{O relato da participante e o contexto histórico: reconstruindo a história da educação no Brasil entre os anos de 1925 e 1940.}

Antes de iniciarmos o percurso histórico propriamente dito, relacionando-o aos dados que emergiram da entrevista com a participante desta pesquisa, julgamos ser necessário, a fim de situar melhor o leitor acerca do período de escolarização da participante, bem como do início do trabalho docente, sintetizar tais informações. Para tal, contamos com a tabela a seguir:

Tabela 1: Síntese dos períodos e anos que compõem a historiografia de formação escolar da participante.

\begin{tabular}{lc}
\hline \multicolumn{1}{c}{ PERÍODO } & ANO \\
\hline Nascimento & 1918 \\
Início da escolarização & 1925 \\
Ensino Primário & $1925-1928$ \\
Ensino Complementar & $1929-1931$ \\
Ensino Secundário & $1932-1935$ \\
Ensino Vocacional & $1936-1937$ \\
Início do período docente & 1938 \\
\hline
\end{tabular}

Fonte: Construção das autoras.

Em relação ao contexto histórico da educação no Brasil, sobretudo ao ensino de língua materna, Soares (2002) conta a história da constituição da disciplina de Português na escola por vários séculos, desde o início das disciplinas curriculares (século XVI) até as grandes reformas da década de 1980. A autora aponta as principais mudanças na educação escolar, explicando as razões para elas, que incluem fatores tanto de natureza social, política e cultural quanto pela evolução da área de conhecimento teórico sobre a língua(gem).

No período focado para este artigo, Soares (2002) relata que, em meados do século XX (até a década de 40), a disciplina denominada Português ainda mantinha a mesma tradição das antigas disciplinas de Gramática, Retórica e Poética. Assim, ainda havia uma visível separação entre gramática e textos, sobretudo no livro didático do professor. A única mudança que ocorreu nesse início de século foi que a retórica e a poética, que antigamente ensinavam "a arte do discurso", agora desenvolviam "técnicas" para o "escrever bem"; ou seja, segundo Soares (2002), o que prevalecia do trivium - gramática, retórica e poética - na disciplina era o ensino de gramática. Esses detalhamentos foram lembrados pela participante da pesquisa, que se referia ao ensino do Português sempre como "ensino da gramática". Não houve nenhuma remissão, durante a entrevista, ao ensino das antigas disciplinas (ou de seus conteúdos) de Retórica e Poética. O que foi relembrado no relato pela participante sobre essa disciplina foram as regras gramaticais.

Quanto aos aspectos social e comportamental, a autora aponta que a escola, nessa época, continuava sendo um privilégio apenas das elites. Apenas os mais ricos da cidade estudavam na escola. A participante referenda essa afirmação ao informar que (1) tinha

Work. pap. linguíst., 13(2): 123- 138, Florianópolis, jul.set,2012 
elemento pobre 3 na escola que frequentou, mas que a prevalência era de colegas pertencentes à elite ou, nas palavras dela, os colegas eram (2) Os filhos do governador, né... A elite... É, mesmo mais a elite.... Além disso, a participante informa que toda sua escolarização se deu em escola pública, já que (3) Naquele tempo era tão raro se pagar estudo... Um certo tempo para cá é que foi apertando....

Quanto à formação profissional, a autora (2002) afirma que não havia ainda faculdade para professor, sendo os docentes apenas formados na educação básica, sobre o que trataremos mais à frente. Além disso, os professores eram os responsáveis pela preparação das aulas: segundo Soares (2002), os livros didáticos eram verdadeiras coletâneas de textos e regras gramaticais, o trabalho de elaborar exercícios e atividades para a aula era de inteira responsabilidade do professor. A participante, entretanto, não relatou informações sobre o fazer pedagógico que corroborassem essas particularidades, porém, como já mencionado, referia-se à disciplina de Português somente como ensino de conceitos gramaticais.

Em sua tese, que acaba por abordar, mesmo que tangencialmente, a constituição da disciplina de Língua Portuguesa, Razzini (2000), em estudo que ancorou a discussão feita por Soares (2002), afirma que, até 1931, o curso secundário não tinha conclusão obrigatória para o ingresso nos cursos superiores, cuja seleção era feita pelos "Exames Preparatórios", o que fez com que o currículo do curso secundário estabelecesse uma relação de dependência em função de tais exames.

Em relação especificamente à disciplina de Português, Razzini (2000) relata que, a partir de 1925, a Lei Rocha Vaz (decreto 16.782-A, de 13 de janeiro de 1925), assinada pelo ministro João Luiz Alves, promoveu um aumento de $66 \%$ nas aulas de vernáculo, ou seja, essas aulas passaram para quinze horas e ocupavam cinco séries do curso secundário, que foi estendido para seis anos. Sobre o conteúdo estudado, descreve a autora: "O ensino do vernáculo em 1926 era predominantemente gramatical. A gramática normativa era enfatizada no primeiro e no segundo ano, enquanto que alguns tópicos da gramática histórica eram reservados para o terceiro ano." (RAZZINI, 2000, p. 97). Assim, leitura e redação eram secundarizadas pela gramática normativa. No currículo das outras línguas, inclusive no de Latim, o ensino gramatical também tinha preferência.

A participante não referiu o enfoque dado nas aulas de Português ou de Francês e Alemão, mas citou algumas disciplinas cursadas:

(4) Era curso complementar, 4 anos, tinha que fazer isso que era para entrar no curso complementar. Eram 3 anos, eu fiz com 3 anos. E com línguas, francês e alemão. E, não sei para que, agricultura, tipo o arado, as peças do arado tinha que saber e para que é que serviam. Educação moral e cívica.

Para uma maior compreensão dessas características da disciplina de Português relatadas pelas autoras, vale descrevermos o contexto social da época selecionada para este artigo - década de 20 a 50. Podemos encontrar um breve histórico desse período na tese de

\footnotetext{
${ }^{3}$ Não usaremos técnicas de transcrição prescritas pela Análise da Conversação. Reconhecemos a importância dessas técnicas, mas optamos por prescindir delas aqui, dado o fato de este estudo não se filiar a áreas em que os detalhes dessas transcrições se revelem inerentemente significativos. Vamos, no entanto, manter as marcas de oralidade nas transcrições.
}

Work. pap. linguíst., 13(2): 123- 138, Florianópolis, jul.set,2012 
Daniel (2001), que analisa a história da disciplina Português em uma escola normalista da cidade de Campo Grande, Mato Grosso, durante as décadas de 30 e 40. A autora divide a descrição histórica do período em contexto nacional, estadual e da escola em estudo, apontando fatos ocorridos nos campos da política e da educação.

No contexto nacional, no campo da política, Daniel (2001) relembra as crises e as radicalizações ocorridas na década de 30 , marcadas, sobretudo, pela revolução de Getúlio Vargas, que virou presidente da república com o apoio da classe média emergente. Em 1932, a sociedade paulista se voltou contra Getúlio, após a revolução Constitucionalista. Enquanto estouravam as revoluções políticas, a crise econômica internacional aumentava drasticamente, e o capitalismo promovia urbanização e industrialização. Razzini (2000) também se refere a esse fato histórico, ao afirmar que a Revolução de outubro de 1930, que depôs o presidente Washington Luís e marcou a ascensão de Getúlio Vargas, trouxe determinações diferentes para às ações educativas no Brasil. Todas essas mudanças políticas não foram citadas pela participante durante a entrevista, provavelmente por não terem gerado impacto significativo nas ações didático-pedagógicas vivenciadas pela participante na condição de aluna.

Já no campo da educação, Daniel (2001) conta que a escola, nesse período, estava se tornando cada vez mais "brasileira", ou seja, abandonando as características importadas do exterior (sobretudo da Europa) e desenvolvendo suas próprias especificações. Em 1930, houve a criação do Ministério da Educação e Saúde, com o ministro Francisco Campos. Com o ministério formado, o Estado passou a atuar efetivamente na educação por meio de decretos, como os apontados pela autora:

- decreto $n^{0} 19.850$ (11/04/1931): cria o Conselho Nacional de Educação;

- decreto $n^{0} 19.851$ - (11/04/1931): dispõe sobre a organização do ensino superior no Brasil e adota o regime universitário;

- decreto $\mathrm{n}^{0} 19.852$ - (11/04/1931): dispõe sobre a organização da Universidade do Rio de Janeiro;

- decreto $n^{0} 19.890$ - (18/04/1931): dispõe sobre a organização do ensino secundário;

- decreto $n^{0} 20.158$ - (30/06/1931): organiza o ensino comercial, regulamenta a profissão de contador e dá outras providências;

- decreto $n^{0} 21.241$ - (14/04/1932): consolida as disposições sobre a organização do Ensino Secundário.

Todos esses decretos fizeram parte da chamada Reforma Francisco Campos (decreto 19.890, de 18 de abril de 1931, e decreto 21.241, de 4 de abril de 1932), cuja principal mudança implantada na educação foi a criação do ensino comercial, posterior ao ensino secundário. Com essa reforma, o aluno estudava cinco anos do ensino primário, dois anos no complementar e ainda de um a três anos no ensino comercial, dependendo do curso escolhido.

A participante passou por essa reforma justamente quando estava no primeiro ano do ensino secundário, em 1932. A entrevistada não soube precisar o ano exato da mudança, mas demonstrou-se insatisfeita em ter seus estudos estendidos por mais dois anos, ao que ela chamou de "ensino vocacional". Não soubemos explicar a diferença de nomenclatura, mas, pela descrição e as datas apontadas, parece tratar-se do mesmo "ensino comercial" estabelecido pela reforma. Eis o seu relato:

Work. pap. linguíst., 13(2): 123- 138, Florianópolis, jul.set,2012 
(5) Depois, no segundo ano, tu vê como é chato, segundo ano peguei a reforma. [...]. Secundário eram 3, 4 [...] 4 anos, era o antigo normal, né. O antigo normal. Aí tinha que fazer o vocacional. Tu vê, no segundo ano, secundário, tinha que fazer o vocacional. Foi a reforma no ensino. Ai eram mais 2 anos, mais 2 anos, era [...] Psicologia, filosofia, sociologia, e outras "ias", né [...] Com 2 anos [...] Tu já pensasse?

A participante informou também não ter realizado nenhum tipo de prova ao terminar o ensino primário, mas refere que, em lugar da prova de admissão para o secundário, (6) fazia-se o curso complementar por três anos, como pode ser observado na Tabela 1, apresentada anteriormente, que sistematiza o percurso escolar da participante. Com relação ao currículo do curso complementar, a participante relata que (7) [...] era de tudo. Educação Física [...] Tinha agricultura [...] Tinha alemão, imagina [...]. Desse período, foi encontrado no acervo da entrevistada um único livro didático de História do Brasil, o que aponta para mais uma disciplina do curso complementar. O livro trazia o nome da participante como aluna do segundo ano da "escola complementar" e a data de cinco de março de 1930.

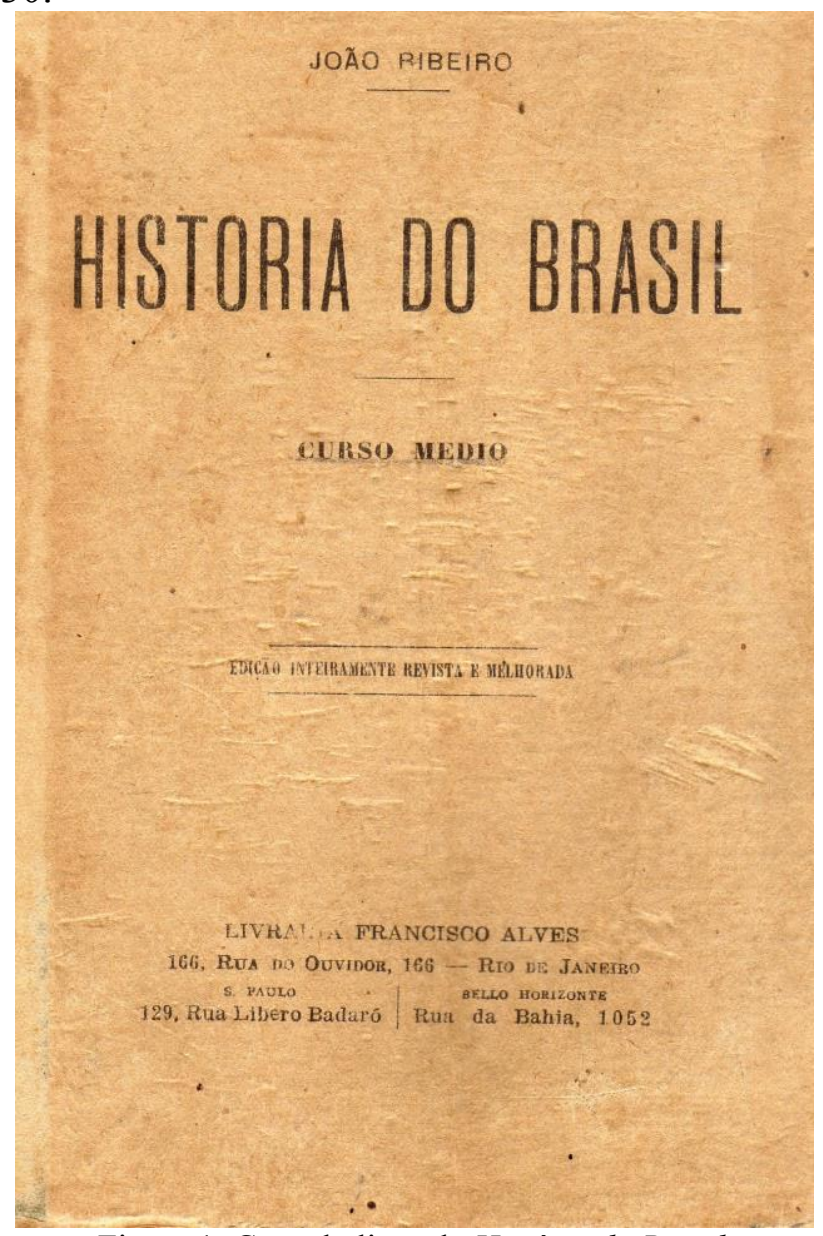

Figura 1: Capa do livro de História do Brasil

Fonte: acervo da participante.

Work. pap. linguíst., 13(2): 123- 138, Florianópolis, jul.set,2012 
Para ilustrar melhor o que os alunos estudavam nessa época, Daniel (2001, p. 12) levanta os quadros das disciplinas obrigatórias em cada ciclo do ensino primário:

\section{Quadro 1}

Ciclo Fundamental: matérias obrigatórias

\begin{tabular}{|l|l|l|l|l|}
\hline $1^{\circ}$ ano & $2^{\circ}$ ano & $3^{\circ}$ ano & $4^{\circ}$ ano & $5^{\circ}$ ano \\
\hline Português & Português & Português & Português & Português \\
\hline Francês & Francês & Francês & Francês & \\
\hline & Inglês & Inglês & Inglês & \\
\hline & & & Latím & Latím \\
\hline Matemática & Matemática & Matemática & Matemática & Matemática \\
\hline Ciências & Ciências & & & \\
\hline & & História Natural & História Natural & História Natural \\
\hline & & Física & Física & Física \\
\hline História & Química & Química & Química \\
\hline Geografia & História & História & História & História \\
\hline Desenho & Geografia & Geografia & Geografia & Geografia \\
\hline Música & Desenho & Desenho & Desenho & Desenho \\
\hline Alemão - Matéria & Opúsica & Música & & \\
\hline
\end{tabular}

Fonte: Gonçalves \& Pimenta (1992: 32)

Fonte: Gonçalves \& Pimenta, 1992, p. 32 apud Daniel, 2001, p. 12.

Quadro 2

Ciclo Complementar: matérias obrigatórias

\begin{tabular}{|c|c|c|c|c|c|}
\hline \multicolumn{2}{|l|}{ Direito } & \multicolumn{2}{|c|}{$\begin{array}{c}\text { Medicina } \\
\text { Odontologia } \\
\text { Farmácia }\end{array}$} & \multicolumn{2}{|c|}{$\begin{array}{l}\text { Engenharia } \\
\text { Arquitetura }\end{array}$} \\
\hline $1^{\circ}$ ano & $2^{\circ}$ ano & $1^{\circ}$ ano & $2^{\circ}$ ano & $1^{\circ}$ ano & $2^{\circ}$ ano \\
\hline Literatura & Literatura & Alemão/Inglês & Alemão/Inglês & & \\
\hline Latim & Latim & & & & \\
\hline Psicologia e Lógica & & Psicologia e Lógica & & Psicologia e Lógica & \\
\hline Noções de Economia & Sociologia & & Sociologia & & Sociologia \\
\hline \multicolumn{6}{|l|}{ E Estatistica } \\
\hline Biologia Geral & Higiene & & & & \\
\hline \multicolumn{6}{|l|}{ História } \\
\hline & Geografia & & & & \\
\hline & História & & & & \\
\hline & Filosofia & & & & \\
\hline & & Matemática & & Matemática & Matemática \\
\hline & & Fisica & Física & Fisica & Fisica \\
\hline & & Química & Química & Química & Química \\
\hline & & História Natural & História Natural & História Natural & História Natural \\
\hline & & & & Geografia e & \\
\hline & & & & Cosmologia & \\
\hline & & & & & Desenho \\
\hline
\end{tabular}

Fonte: Gonçalves \& Pimenta (1992: 32)

Fonte: Gonçalves \& Pimenta, 1992, p. 32 apud Daniel, 2001, p. 12.

Acerca ainda das matérias que constituíam o quadro de disciplinas do vocacional e a recepção disso por parte dos alunos, a participante novamente mostra insatisfação com as

Work. pap. linguíst., 13(2): 123- 138, Florianópolis, jul.set,2012 
mudanças geradas pela reforma, por terem excluído as disciplinas ditas como "básicas" do ensino, como Português, Matemática e Geografia:

(6) O principal, português, matemática, não tinha. Entendes? Era só psicologia, "psi" "psi” e lá vai dose [...] Aí nós fomos ao palácio [...] Nós fomos ao palácio [...] Uma turma grande. Pedir para ser incluídas as antigas matérias. Porque nós não tínhamos uma base firme para ficar assim, não tínhamos [...] Era aquilo, sempre por alto né [...] E [...] Aí foram incluídas as matérias mais as matérias do vocacional. [...] Eles escreviam, eles queriam que fosse assim [...] Que fosse só determinadas matérias [...] Entendes? Mas nós fomos a palácio pedir ao governador que não, que não tinha português, não tinha matemática, que era o principal, né. Português, matemática, geografia [...] Não tinha, era só assim psicologia, filosofia, sociologia [...] Entendes? E, ai foi, aumentaram tudo, imagina que angú do caroço! Ficaram todas as matérias! Inclusive música. Música, nós tínhamos quase que [...] Não era voluntário [opcional] não, era obrigada.

Romanelli (1983) também critica a Reforma Campos, que teria marginalizado o ensino primário e normal:

A reforma deixou completamente marginalizados os ensinos primário e normal e os vários ramos do ensino médio profissional, salvo o comercial. Praticamente, a reforma tratou de organizar preferentemente o sistema educacional das elites. A obrigatoriedade de se prestarem exames para admissão ao ensino médio, nos quais se exigiam conhecimentos jamais fornecidos pela escola primária, importava em reconhecer a nulidade desta. (ROMANELLI, 1983 apud DANIEL, 2001, p. 15).

Por outro lado, segundo Razzini (2000), a obrigatoriedade da conclusão do curso secundário fundamental para a entrada nos cursos superiores estabilizou o curso fundamental e suas disciplinas, ou, por outra, "[...] independente da carreira que o aluno fosse escolher depois, o tempo de sua formação "fundamental" era composto de um terço de línguas, um terço de matemática e ciências, e um terço dividido entre história e geografia e desenho e música." (RAZZINI, 2000, p. 99). No total, eram ministradas 16 horas semanais de português, nove horas de francês, nove horas de inglês e apenas seis horas de latim. O alemão era optativo nessa época. Essa configuração do ensino de línguas "[...] ressalta a precedência do estudo do vernáculo sobre as outras línguas e a queda do ensino clássico na formação fundamental" (RAZZINI, 2000, p. 99).

A autora também relata que o programa de português, expedido pelo Ministério da Educação e Saúde com os demais programas do curso fundamental em 30 de junho de 1931, privilegiava o ensino a partir da leitura dos cânones literários. Tal leitura não tinha autores pré-definidos pelo programa, tampouco suas nacionalidades. No entanto, o programa em questão propunha uma "[...] ordem cronológica inversa, começando pelos 'prosadores e poetas contemporâneos' nas duas primeiras séries, passando pelos 'modernos' e os do século XIX, na $3^{\mathrm{a}}$ e na $4^{\mathrm{a}}$ série, indo até os do 'período' clássico, na $5^{\mathrm{a}}$ série.” (RAZZINI, 2000, p. 99). Isso estava embasado na compreensão de que as obras modernas estavam próximas aos leitores, por isso provocariam emoções sinceras, prazer dos estudos e poderiam contribuir para educar o gosto literário. Assim, ao que parece, essa nova configuração do ensino de português dos anos 1930, segundo Razzini (2000), privilegia uma abordagem menos teórica da gramática, febre nos anos 1920. Nossa 
participante de pesquisa não soube precisar tais questões, simplesmente por não se recordar de tais pormenores.

Retomando a passagem do ensino secundário ao ensino superior, mencionada por Razzini (2000), ou, no caso de nossa participante de pesquisa, do término do vocacional e do início das atividades como docente, a participante refere que, normalmente, ao final do vocacional, os alunos tinham de fazer o exame final; ela, no entanto, não o fez, visto que tinha média sobrando ou, nas palavras dela (9) Eu não fiz [o exame final]. Eu não fiz. Tinha tanta média, que não precisei fazer. Segundo a entrevistada, só faziam o exame final aqueles alunos que não atingiam uma média mínima para finalizar os estudos, cujo valor exato ela não soube apontar.

Embora a participante não lembre exatamente da nomenclatura utilizada para o título atribuído aos formados ao final do vocacional, ela confirma que, ao terminá-lo, o aluno podia dar aula, asseverando (10) Eu não me lembro exatamente como... Pode ser depois com o decorrer eu me lembre. [...] Era assim... Os que tirassem melhor nota eram os primeiros a escolher o lugar [para dar aula], né. Eu sempre fui... Assim, segundo a participante, os alunos que concluíssem os estudos com as melhores notas possuíam o "privilégio" de escolher o local para dar aula.

Sobre o início do período laboral como docente em turma de alfabetização nos quatro anos do primário, no município de Araranguá/SC, a participante menciona sua preocupação com o fazer didático-pedagógico associado à realidade dos alunos, ao que ela chama de prática, como ilustra o fragmento da entrevista abaixo:

(11) O grupo [escolar] era tão bom que tava caindo aos pedaços. Era na estrada que ia para Porto Alegre. Ai, me dava uma raiva, que eu sempre dava aula de matemática era prática, aula prática. Então eu não fazia, de maneira que eu não ficasse na classe... Eram os alunos, entende? [...] Eles faziam probleminha assim, claro que, dentro do limite né... Era primeiro aninho. Eles faziam um problema, conversavam dois como se estivessem de fato conversando... Então, eu ia indo para casa e encontrei-me com ciclano, e formava o problema né... Quanto é que deu? O outro assim... Sabes? Dizia que não com a cabeça. $O$ outro dizia assim: pois olha, pois é muito simples... Eles conversando... É muito simples, pois se ele tinha tanto e comprou mais tanto, quanto é que ficou? Ah tá, agora já sei, deixa eu responder? Tudo assim, bem prática...

Essa atenção dada ao ensino mais voltado para a práxis impactava o ensino do vernáculo também, o que é visível nos programas de ensino:

[...] foi reafirmada por Abgar Renault, diretor geral do Departamento Nacional de Educação, quando expediu a Portaria 190, em 24 de abril de 1939, para instruir 'inspetores, diretores e professores de estabelecimentos de ensino secundário [...] sobre o ensino da língua e da história nacional'. Depois de orientar o ensino da história nacional e as aulas de português, que deveriam ser compostas de dois terços de exercícios orais e de redação, sendo que, a esta última caberia $60 \%$ da nota das provas. (RAZZINI, 2000, p. 100).

A autora afirma ainda que a centralização e o controle dos livros didáticos a partir do Ministério da Educação e Saúde, tirando mais essa função do Colégio Pedro II, durante o Estado Novo (1937-1945) de Getúlio Vargas, foi uma grande mudança. Foi com o

Work. pap. linguíst., 13(2): 123- 138, Florianópolis, jul.set,2012 
decreto 1.006, de 30 de dezembro de 1938, que foi criada a Comissão Nacional do Livro Didático. Tal comissão era responsável por examinar, julgar e autorizar o uso de todos os livros didáticos do ensino primário e secundário. Não houve remissões a esses fatos históricos na entrevista da participante.

Razzini (2000) também relata que, em 30 de abril de 1931, foi firmado o primeiro acordo ortográfico entre a Academia Brasileira de Letras e a Academia de Ciências de Lisboa, tendo sido implantado em repartições públicas, em estabelecimentos de ensino, no Diário Oficial e nas demais publicações oficiais, pelo decreto 20.108, de 15 de junho de 1931. A Academia Brasileira de Letras, autoridade oficial, preparou o Vocabulário Ortográfico e Ortoépico da Língua Portuguesa, que passou a vigorar no país a partir de sua publicação, em 1932. Segundo a autora, o acordo ortográfico, bem como o currículo de português, resultavam de uma compreensão da língua como responsável pela implantação da cultura nacional. Sobre o acordo ortográfico e as implicações no fazer escolar, a participante relata criticamente:

(12) Teve uma reforma do ensino, e também na ortografia. Ortografia mudou... E gramaticalmente falando, não achei [...] finalidade alguma. Mudou muito, embaralhou tudo e não deu resultado, entendes? Porque, por exemplo, olha "o gelo é branco", não, "o branco é que é gelo"... Entendes? Dá na mesma batata... E a outra maneira era muito melhor de aprender, porque a gente já estava acostumados com aquelas regrinhas de gramática, né. E depois passar assim, abruptamente, para outra... E não se via diferença no escrever, mas na ciência mesmo...

Podemos ter uma noção das diferenças ortográficas nessa época no trecho inicial do livro de História do Brasil mencionado, encontrado no acervo da participante. $\mathrm{O}$ ano de publicação é de 1928:

Work. pap. linguíst., 13(2): 123- 138, Florianópolis, jul.set,2012 


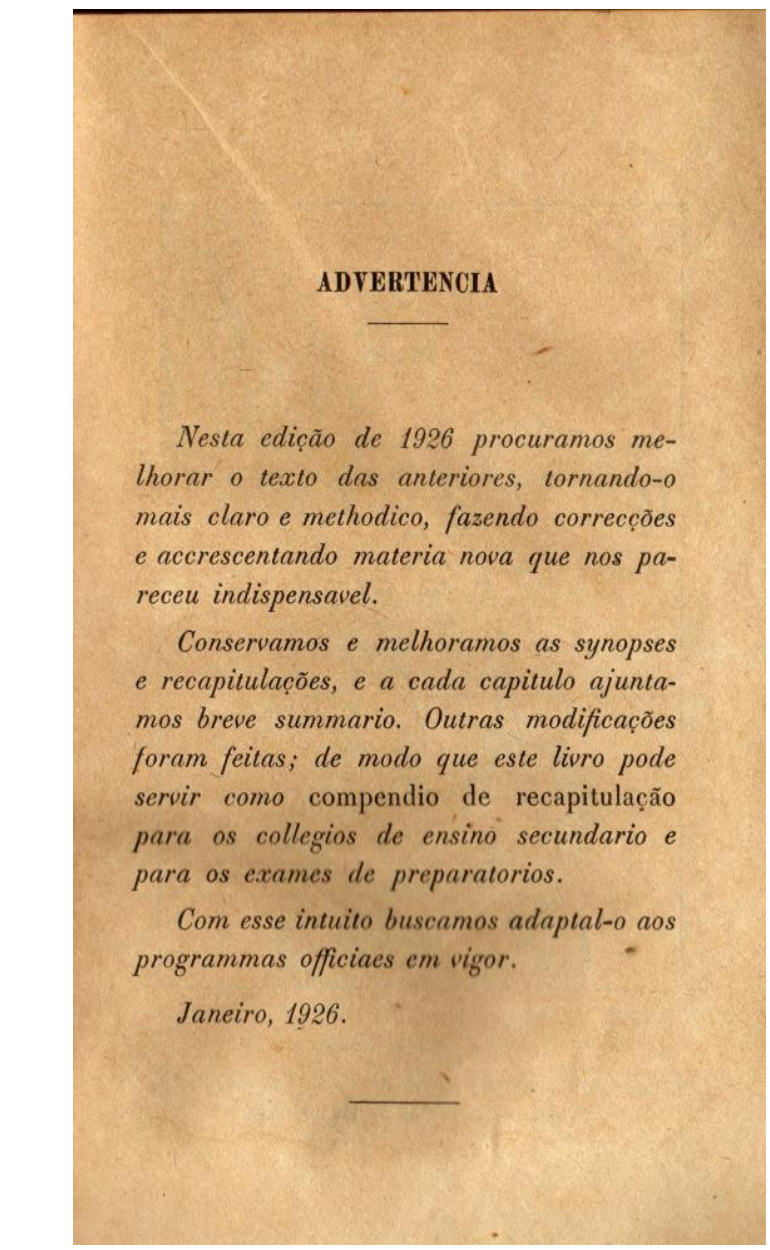

Figura 2: Apresentação do livro de História do Brasil, 1928 Fonte: acervo da participante.

Outro fato histórico que trouxe significativas mudanças para a educação no Brasil, segundo Daniel (2001), foi a constituição de 1934, que exigiu gratuidade e obrigatoriedade do ensino primário, direito à educação, liberdade de ensino e ensino religioso de caráter "interconfessional" (facultativo). Além dessas diretrizes, Daniel (2001) também aponta para a criação das faculdades de Filosofia, Ciências e Letras da Universidade de São Paulo, que implantou a formação de professores de línguas e literaturas em nível de ensino superior, e a queda de prestígio do Colégio Pedro II - referência a grande parte das escolas brasileiras.

Em 1937, foi implantada uma nova Constituição, conhecida como a polaca. A autora (2001) aponta como principais ações dessa constituição: continuou a fixar as bases e determinar os quadros da educação nacional, traçando as diretrizes na área educacional; manteve a gratuidade e a obrigatoriedade do ensino; deu maior destaque ao ensino profissional "para as classes menos favorecidas" (discriminação social); proclamou a liberdade da iniciativa individual e das associações públicas e particulares, com relação ao ensino; foi mais moderada sobre o ensino religioso.

Ainda no campo da educação, em nível nacional, Daniel (2001) conta sobre a criação das chamadas escolas normais: foi no século XIX, inicialmente só para homens. 
Conforme relata a autora, foi na década de 1920 - período republicano - que as escolas normais adquiriram caráter profissionalizante - formação de professores para ensino primário - e passou a aceitar mulheres. As matérias eram, portanto, de preparação técnicopedagógica, e a grande referência nacional era a cidade de São Paulo. Daniel (2001) explica a articulação que houve entre esse curso e o secundário:

Antes de 1930, havia em São Paulo completa separação entre o curso secundário (ginasial), destinado às elites que se preparavam para o ingresso no ensino superior e ministrado em estabelecimentos particulares e nos três ginásios do Estado (da Capital, de Ribeirão Preto e de Campinas), e o Curso Normal, de caráter terminal e destinado à formação de professores primários. Para um jovem tornar-se professor primário, ao final da Primeira República, deveria seguir, de um modo geral, os seguintes estudos: $1^{\circ}$ - Curso Primário (preliminar); $2^{\circ}-$ Curso Complementar; $3^{\circ}$ - Curso Normal. Com as reformas de Francisco Campos foi possível em São Paulo expandir-se os cursos ginasiais, ampliar o número de ginásios do Estado e assim abolir-se o curso complementar, substituindo-o pelo Ginásio. Passou, assim, o curso normal a ser um curso de segundo ciclo, definido como um ramo especificamente pedagógico, isto é, sem disciplinas de caráter geral (já ministradas no ginásio). (ANTUNHA, 1973 apud DANIEL, 2001, p. $16)$.

Mesmo não tendo citado em nenhum momento da entrevista o nome da escola, podemos inferir que a participante estudou em uma dessas escolas ditas "normais", uma vez que se tornou professora ao se formar. Novamente, esses detalhamentos não foram relembrados pela entrevistada.

Já a década de 40, segundo Razzini (2000), foi caracterizada por várias reformas às ações educativas, as chamadas Leis Orgânicas, sendo a maioria implementada sob o Estado Novo (1937-1945) de Getúlio Vargas. Em 1942, foi promulgada a Lei Orgânica do Ensino Secundário por meio do decreto-lei 4.244, assinado pelo ministro Gustavo Capanema. A reforma Capanema, como foi chamada, dividiu o curso secundário em duas partes: o $1^{\circ}$ ciclo - curso ginasial - composto de quatro séries; e o $2^{\circ}$ ciclo, subdividido em curso clássico e curso científico, ambos com três séries. Embora a participante afirme ter presenciado várias reformas durante os períodos discente e docente, ela não menciona de forma flagrante essa reforma, o que provavelmente indica pouco impacto na ação pedagógica, diferentemente da Reforma Francisco Campos.

A reforma Capanema assinalou "[...] a ascensão definitiva do ensino de português no curso secundário, uma vez que sua abrangência e carga horária, daí em diante, só tenderiam a aumentar" (RAZZINI, 2000, p. 104). A reforma Capanema sofreu poucos ajustes nos anos que seguiram e acabou por marcar o ensino secundário até o início dos anos de 1960. Além do aumento no número de aulas de português, "[...] o patriotismo ditou também os temas preferenciais dos textos de leitura no curso ginasial" (RAZZINI, 2000, p. 104). Novamente, não obtivemos nenhuma remissão da entrevistada a esse período histórico.

Do mesmo modo como registramos ainda na seção anterior, a reconstrução de determinados períodos históricos a partir de relatos orais é, na verdade, uma releitura desses períodos à luz das vivências do participante. No caso específico deste estudo, trata-se de uma releitura do percurso da escolarização na condição de discente de uma docente que lecionou por trinta anos, hoje aposentada e com 93 anos. Assim, obviamente, a participante

Work. pap. linguíst., 13(2): 123- 138, Florianópolis, jul.set,2012 
apresenta, quando do relato, longos períodos, especialmente os anos iniciais, em que não recorda de muitos fatos ou pelo menos dos nomes das reformas, dos documentos, dentre outros aspectos, o que será discutido nas considerações finais. Isso, ao nosso ver, entretanto, não diminui a riqueza dos dados aqui apresentados e analisados.

\section{Considerações finais}

Quando tomamos o conjunto de dados que compõe essa pesquisa e o relacionamos com o percurso histórico construído por Razzini (2000), Soares (2002) e Daniel (2001), observamos muitas lacunas nos relatos orais da participante, o que pode ser explicado por dois fatores: (1) ao gerar-se dados a partir de relatos orais ou memórias com intenção de reconstrução de determinado período histórico, são relatados pelos participantes os episódios que marcaram efetivamente tal período, os quais muitas vezes não coincidem com o recorte específico proposto para a pesquisa a priori, eis a diferença entre memória e lembrança; e (2) os relatos orais devem ser tomados como as memórias refratadas de um período, em nosso caso discente e início do período docente, de um sujeito de hoje, com muitas vivências depois daquele período. Além disso, pode-se também destacar o fator idade, que também influenciou o processo de reconstrução da memória, visto que evidenciou perda de memória em decorrência da idade - 93 anos.

Assim como observamos ao longo da análise, por fim, muitas reformas, ortográficas e de ensino, aconteceram durante o período compreendido entre 1925 e 1940; algumas, porém, impactaram mais o percurso escolar, quer seja como discente ou docente, como o caso da Reforma Francisco Campos, e outras menos, como parece ser o caso da Reforma Capanema no contexto de nossa participante de pesquisa. Podemos inferir que os fatos mais citados pela entrevistada foram os que mais marcaram sua vida de estudante e de professora iniciante.

Tais reformas, quaisquer que sejam sua natureza, parecem também levar um tempo para reverberar no espaço escolar, haja vista as lacunas cronológicas encontradas entre as datas de formulação dos decretos e os relatos da participante. As reformas de ensino parecem significar mais aos discentes quando dizem respeito a questões administrativas, como foi o caso da inclusão do vocacional tão referida pela participante de pesquisa. Já na perspectiva docente, são as reformas ortográficas que parecem ser mais significativas no espaço escolar, como demonstrou nosso conjunto de dados.

Este artigo, assim, trouxe alguns pequenos trechos do relato oral da participante, que, apesar de apresentar as lacunas referidas, sinalizaram para possíveis respostas a nossa pergunta de pesquisa: Como as reformas políticas na educação do Brasil, no período entre 1925 e 1940, incidiram nas ações educativas da época, principalmente no que compete à disciplina de Língua Portuguesa? Infelizmente, a idade avançada limitou as lembranças dessa personagem viva da história. Há muito ainda para ser pesquisado e compreendido, mas o pouco que se pode levantar, através de relatos orais, já se constituiu em um rico material na reconstrução da história do ensino no Brasil.

Work. pap. linguíst., 13(2): 123- 138, Florianópolis, jul.set,2012 


\section{Referências}

DANIEL, M. E. B. Uma história da disciplina Português no ensino normal: 1930-1940. 2001. Tese (doutorado em Linguística). Faculdade de Filosofia, Letras e Ciências Humanas, Universidade de São Paulo, São Paulo.

FRIEDEMANN, Andréia Regina Sarmento. Memórias de leitura do professor de Língua Portuguesa: uma análise das práticas de leitura de professores da Educação Básica. Dissertação (Mestrado) - UFSC, Florianópolis, 2010.

JANOTTI, Maria de Lourdes M.. A incorporação do testemunho oral na escrita historiográfica: empecilhos e debates. História Oral, v. 13, n. 1, p. 9-22, jan./jun. 2010.

MARCONI, Marina de Andrade; LAKATOS, Eva Maria. Fundamentos da metodologia científica. 6. ed. 4. reimpr. São Paulo: Atlas, 2007.

RAZZINI, M. P. G. O espelho da nação: a Antologia Nacional e o ensino de português e literatura (1838-1971). 2000. Tese (Doutorado em Teoria Literária) - Instituto de Estudos da Linguagem, Universidade Estadual de Campinas, Campinas, SP.

SMITH, Richard C.. História oral na historiografia: autoria na história. História Oral, v. 13, n. 1, p. 23-32, jan/jun. 2010.

SOARES, M. Português na escola - história de uma disciplina curricular. In: BAGNO, Marcos. (Org.). Lingüística da norma. São Paulo: Loyola, 2002. p. 155-177.

Work. pap. linguíst., 13(2): 123- 138, Florianópolis, jul.set,2012 